\title{
Impact of rifampicin dose in bone and joint prosthetic device infections due to Staphylococcus spp: a retrospective single- center study in France
}

\author{
M. Tonnelier ${ }^{1,2^{*}}$ (D, A. Bouras ${ }^{1}$, C. Joseph ${ }^{1,3}$, Y. El Samad ${ }^{1}$, B. Brunschweiler ${ }^{4}$, J.-L. Schmit ${ }^{1,3}$, C. Mabille 5 and
} J-P Lanoix ${ }^{1,3}$

\begin{abstract}
Background: Prosthetic joint infections (PJI) are a major cause of morbidity and mortality burden worldwide. While surgical management is well defined, rifampicin (RIF) dose remains controversial. The aim of our study was to determine whether Rifampicin dose impact infection outcomes in PJI due to Staphylococcus spp.

Methods: single-center retrospective study including 411 patients with PJI due to Rifampicin-sensitive Staphylococcus spp. Rifampicine dose was categorized as follow: $<10 \mathrm{mg} / \mathrm{kg} / \mathrm{day}, 10-20 \mathrm{mg} / \mathrm{kg} /$ day or $>20 \mathrm{mg} / \mathrm{kg} /$ day. The primary endpoint was patient recovery, defined as being free of infection during 12 months after the end of the initial antibiotic course.

Results: 321 (78\%) received RIF for the full antibiotic course. RIF dose didn't affect patients recovery rate with 67, 76 and $69 \%$ in the $<10,10-20$ and $>20 \mathrm{mg} / \mathrm{kg} /$ day groups, respectively $(p=0.083)$. In univariate analysis, recovery rate was significantly associated with gender $(p=0.012)$ but not to RIF dose, or Staphylococcus phenotype (aureus or coagulase-negative). In multivariate analysis, age $(p=0.01)$ and treatment duration $(p<0.01)$ were significantly associated with recovery rate.
\end{abstract}

Conclusion: These data suggest that lower doses of RIF are as efficient and safe as the recommended high-dose French regimen in the treatment of PJI.

Keywords: Prosthesis-related infections, Staphylococcus, Rifampicin, Adverse effects, Safety

\section{Background}

The disease burden of bone and joint prosthetic device infections (PJI) is high [1-3], because of a need for intensive care in $6 \%$ of cases and an estimated inhospital lethality of 5\% [4], increasing with age.

\footnotetext{
*Correspondence: mathilde.tonnelier87@gmail.com; m.tonnelier@chcompiegnenoyon.fr

'Infectious diseases department, CHU Amiens Nord, 1 place Victor Pauchet, 80000 Amiens, France

${ }^{2}$ Centre hospitalier Compiègne-Noyon - service MIPI, 8 avenue Henri Adnot, 60200 Compiègne, France

Full list of author information is available at the end of the article
}

Length of stay is high (between 18 and 21 days) and repeated admission rate is estimated at $19.3 \%$, with increasing costs $[1,5,6]$.

For PJI due to sensitive germs, Rifampicin (RIF) is a cornerstone, owing to its high bone and tissue diffusion and its action in biofilm [7, 8]. RIF is always used in combined therapy, most frequently with Fluoroquinolones [9-11], with an overall recommended antibiotics course duration of 6 to 12 weeks [9].

However, the ideal RIF dose for PJI is not clearly defined, varying from 5 to $20 \mathrm{mg} / \mathrm{kg} /$ day depending on the

(c) The Author(s). 2021 Open Access This article is licensed under a Creative Commons Attribution 4.0 International License, which permits use, sharing, adaptation, distribution and reproduction in any medium or format, as long as you give appropriate credit to the original author(s) and the source, provide a link to the Creative Commons licence, and indicate if changes were made. The images or other third party material in this article are included in the article's Creative Commons licence, unless indicated otherwise in a credit line to the material. If material is not included in the article's Creative Commons licence and your intended use is not permitted by statutory regulation or exceeds the permitted use, you will need to obtain permission directly from the copyright holder. To view a copy of this licence, visit http://creativecommons.org/licenses/by/4.0/. The Creative Commons Public Domain Dedication waiver (http://creativecommons.org/publicdomain/zero/1.0/) applies to the data made available in this article, unless otherwise stated in a credit line to the data. 
study [12-15]. The 2009 French guidelines suggested 10 $\mathrm{mg} / \mathrm{kg}$ of RIF twice a day (i.e. $20 \mathrm{mg} / \mathrm{kg} /$ day) [9], whereas American guidelines (2013) did not take patient weight into account and recommended lower doses of 600 to $900 \mathrm{mg}$ daily, taken once or twice (i.e. $8-12 \mathrm{mg} / \mathrm{kg} /$ day for a standard $75 \mathrm{~kg}$ person) [14].

Without clear data on outcomes according to RIF dose, clinicians are often guided by experiences of poor tolerance of high RIF dose $[11,16]$. However, up today all pharmacokinetics studies have failed to demonstrate a correlation between RIF serum concentrations and occurrence of adverse events (AEs) $[16,17]$. The rate of AEs linked to RIF in PJI varies between 4.3 and $31.2 \%$ depending on the study [12, 18-20], often attributed to variable inter-individual susceptibilities [21, 22]. Because some studies, although with low sample sizes, suggest that lowerdose RIF could remain effective while improving the drug's tolerance $[12,20]$, tendency of low-dose RIF has become common without guidelines changes.

The aim of our study was to compare recovery rate in PJI due to Staphylococcus spp. between low-dose $(<10$ $\mathrm{mg} / \mathrm{kg} /$ day $)$, intermediate dose $(10-20 \mathrm{mg} / \mathrm{kg} /$ day $)$ and high-dose ( $>20 \mathrm{mg} / \mathrm{kg} /$ day) RIF. We also aimed to compare AEs occurrence in both groups.

\section{Methods \\ Settings}

This retrospective monocentric study was conducted in the Orthopedic Surgery Unit of a University Hospital in Amiens, France between January 2008 and December 2018. Our common practice in Staphylococci PJI is immediate surgery, and probabilistic IV therapy. Then after 5-7 days, oral switch to RIF plus another antibiotic is the rule. During surgery, local antimicrobials in bone cement (containing gentamicin) can be used in hip and knee infections.

Medical records were screened with the assistance of the institution's Medical Information Department. We recorded data using the Electronic Medical Records system (EMR).

Inclusion criteria were as follows: adults over 18 years of age, hospitalized for a PJI due to RIF-sensitive Staphylococcus spp., treated by antibiotics regimen which included RIF for the all course of treatment.

We excluded patients with simultaneous fungal or mycobacterial infection, patients with missing data for the primary endpoint and patients with unknown RIF dose.

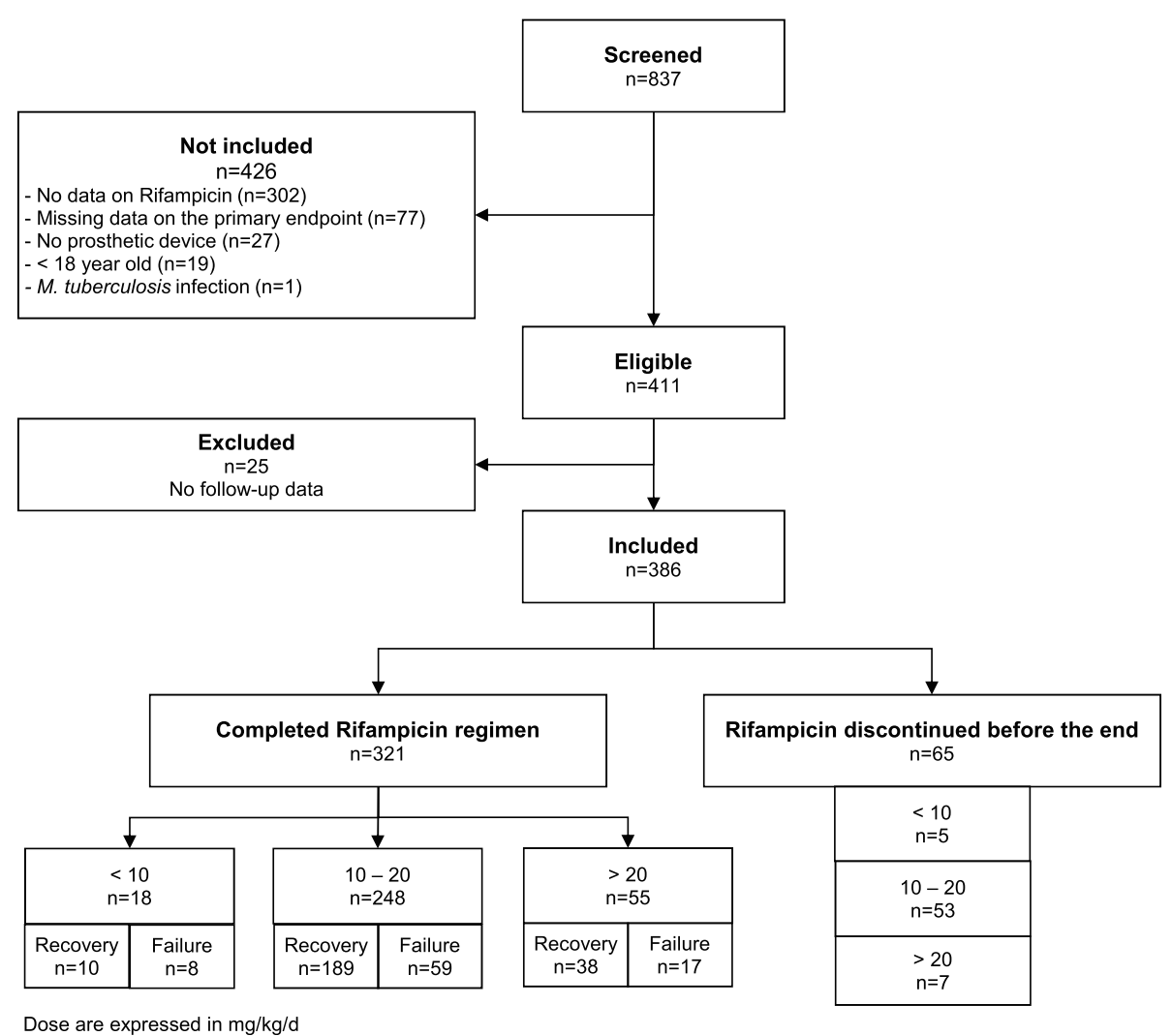

Fig. 1 Flow chart of the study 
Table 1 Study population characteristics

\begin{tabular}{|c|c|c|c|c|}
\hline & Total & $\begin{array}{l}\text { Low-dose }(<10 \mathrm{mg} / \mathrm{kg} / \\
\text { d) }\end{array}$ & $\begin{array}{l}\text { Intermediate-dose }(10-20 \mathrm{mg} / \\
\mathrm{kg} / \mathrm{d})\end{array}$ & $\begin{array}{l}\text { High-dose }(>20 \mathrm{mg} / \mathrm{kg} / \\
\text { d) }\end{array}$ \\
\hline Total, n (\%) & 411 & $27(6.6)$ & $319(77.6)$ & $65(15.8)$ \\
\hline Male sex, $\mathrm{n}(\%)$ & $223(54.3)$ & $9(33.3)$ & $181(56.7)$ & $33(50.8)$ \\
\hline Age, years (mean, [IQR]) & $64.5[55-76]$ & $69.2[61-80]$ & $64.1[55-76]$ & $64.6[51-78]$ \\
\hline Weight, kg (mean, [IQR]) & 82.5 [68-95] & 99.8 [75-125] & 84.5 [70-95] & $65.6[55-80]$ \\
\hline BMI, kg/m² (mean, [IQR]) & $\begin{array}{l}29.1[23.9- \\
33]\end{array}$ & $35.8[27.5-42]$ & $29.4[24.8-33.1]$ & $24.2[20.4-29]$ \\
\hline Obesity, n (\%) & $167(40.1)$ & $20(74.1)$ & $133(41.7)$ & $14(21.6)$ \\
\hline \multicolumn{5}{|l|}{ Comorbidities, n (\%) } \\
\hline Chronic alcohol consumption & $34(8.3)$ & $2(7.4)$ & $26(8.2)$ & $6(9.2)$ \\
\hline Diabetes & $74(8)$ & $7(26)$ & $63(19.7)$ & $4(6.2)$ \\
\hline $\begin{aligned} & \text { Chronic kidney disease } \\
> & \text { grade IIIB }\end{aligned}$ & $18(4.4)$ & $3(11.1)$ & $13(4.1)$ & $2(3.1)$ \\
\hline Immune deficiency factor & $33(10.5)$ & $1(3.7)$ & $26(8.2)$ & $6(9.2)$ \\
\hline Chronic liver disease & $6(1.5)$ & $1(3.7)$ & $4(1.3)$ & $1(1.5)$ \\
\hline \multicolumn{5}{|l|}{ Infection site, n (\%) } \\
\hline Hip & $164(39.9)$ & $7(26)$ & $131(41.1)$ & $26(40)$ \\
\hline Femur & $17(4.1)$ & $0(0)$ & $10(3.1)$ & $7(10.8)$ \\
\hline Knee & $123(9.9)$ & $13(48.1)$ & $94(29.5)$ & $16(24.6)$ \\
\hline Tibia & $29(7.1)$ & $2(7.4)$ & $25(7.8)$ & $4(6.2)$ \\
\hline Ankle & $38(9.2)$ & $4(14.8)$ & $28(8.8)$ & $4(6.2)$ \\
\hline Foot & $13(3.2)$ & $0(0)$ & $11(3.4)$ & $2(3.1)$ \\
\hline Upper limb ** & $28(6.6)$ & $1(3.7)$ & $20(6.3)$ & $6(9.2)$ \\
\hline \multicolumn{5}{|l|}{ Delay of PJI } \\
\hline Acute prosthesis infection ( $<3$ months) & $196(47.7)$ & $13(48.1)$ & $147(46.1)$ & $36(55.4)$ \\
\hline $\begin{array}{l}\text { Chronic prosthesis infection (> } 12 \\
\text { months) }\end{array}$ & $130(31.6)$ & $9(33.3)$ & $104(32.6)$ & $17(26.2)$ \\
\hline \multicolumn{5}{|l|}{ Surgical method } \\
\hline Prosthesis replacement & $212(51.6)$ & $13(48.1)$ & $173(54.2)$ & $24(36.9)$ \\
\hline Prosthetic device removal & $78(19.0)$ & $2(7.4)$ & $59(18.5)$ & $15(23.1)$ \\
\hline Implant retention & $83(20.7)$ & $5(18,5)$ & $59(18.5)$ & $19(29.2)$ \\
\hline Arthrodesis & $5(1.2)$ & $1(3.7)$ & $4(1.3)$ & $0(0)$ \\
\hline Explantation & $31(7.5)$ & $1(3.7)$ & $23(7.2)$ & $6(9.2)$ \\
\hline No surgery & 2 & 0 & 1 & 1 \\
\hline \multicolumn{5}{|l|}{ Germs, n (\%) } \\
\hline Staphylococcus aureus & $289(70.3)$ & $19(70.4)$ & $229(71.8)$ & $42(64.6)$ \\
\hline Methicillin-sensitive & $235(81.3)$ & $18(94.7)$ & $187(81.7)$ & $33(78.6)$ \\
\hline Methicillin-resistant & $51(17.7)$ & $1(5.3)$ & $42(18.39$ & $9(21.4)$ \\
\hline Coagulase negative Staphylococcus & $122(29.7)$ & $8(29.6)$ & $90(28.2)$ & $23(35.4)$ \\
\hline Methicillin-sensitive & $67(54.9)$ & $3(37.5)$ & $51(56.7)$ & $12(52.2)$ \\
\hline Methicillin-resistant & $55(40.6)$ & $5(62.5)$ & $39(43.3)$ & $11(47.8)$ \\
\hline Polymicrobial infection & $107(26)$ & $4(14.8)$ & $87(27.3)$ & $16(24.6)$ \\
\hline \multicolumn{5}{|c|}{ Delay between prosthesis implantation and infection diagnosis, $n(\%)$} \\
\hline$<3$ months & $196(47.7)$ & $13(48.1)$ & $147(46.1)$ & $36(55.4)$ \\
\hline 3-12 months & $85(20.7)$ & $5(18.5$ & $68(21.3)$ & $12(18.5)$ \\
\hline
\end{tabular}


Table 1 Study population characteristics (Continued)

\begin{tabular}{|c|c|c|c|c|}
\hline & Total & $\begin{array}{l}\text { Low-dose }(<10 \mathrm{mg} / \mathrm{kg} / \\
\text { d) }\end{array}$ & $\begin{array}{l}\text { Intermediate-dose (10-20 mg/ } \\
\mathrm{kg} / \mathrm{d})\end{array}$ & $\begin{array}{l}\text { High-dose (> } 20 \mathrm{mg} / \mathrm{kg} / \\
\text { d) }\end{array}$ \\
\hline$>12$ months & $130(31.6)$ & $9(33.3)$ & $104(32.6)$ & $17(26.2)$ \\
\hline \multicolumn{5}{|l|}{ Rifampicin treatment } \\
\hline Dosage, mg/kg/day (mean,[IQR]) & $\begin{array}{l}15.7[12.8- \\
18]\end{array}$ & $8.7[8-9.8]$ & 14.8 [12.9-16.7] & $22.9[20.7-24]$ \\
\hline Full treatment course, n (\%) & $321(78.1)$ & $18(66,6)$ & $55(84)$ & $248(77,7)$ \\
\hline \multicolumn{5}{|l|}{ Combination treatment used } \\
\hline Fluoroquinolones & $278(67.6)$ & $20(74.1)$ & $214(67.4)$ & $44(67.7)$ \\
\hline Clindamycin & $64(15.6)$ & $5(18.5)$ & $51(16)$ & $8(12.3)$ \\
\hline Glycopeptides & $36(8.7)$ & $0(0)$ & $28(8.8)$ & $8(12.3)$ \\
\hline Cotrimoxazole & $17(4.1)$ & $1(3.7)$ & $13(4.1)$ & $3(4.6)$ \\
\hline Penicillin & $6(1.5)$ & $0(0)$ & $6(1.9)$ & $0(0)$ \\
\hline Cephalosporins & $2(0.49)$ & $1(3.7)$ & $1(0.3)$ & $0(0)$ \\
\hline Doxycyclin & $2(0.49)$ & $0(0)$ & $2(0.6)$ & $0(0)$ \\
\hline Daptomycin & $2(0.49)$ & $0(0)$ & $1(0.3)$ & $1(1.5)$ \\
\hline Oxazolidinone & $2(0.49)$ & $0(0)$ & $1(0.3)$ & $1(1.5)$ \\
\hline Fosfomycin & $1(0.24)$ & $0(0)$ & $1(0.3)$ & $0(0)$ \\
\hline Dalbavancin & $1(0.24)$ & $0(0)$ & $1(0.3)$ & $0(0)$ \\
\hline
\end{tabular}

* One or more criteria among the following: active neoplasia dating less than 1 year; immunosuppressive treatment including systemic steroids, chemotherapy or immunomodulatory drugs

** Shoulder, humerus, elbow, forearm, hand

Clinical variables gathered included age, sex, weight, height, body-mass index (BMI), underlying comorbidities such as diabetes, active excessive alcohol consumption, immune deficiency factors (neoplasia in the current year, immunosuppressive treatment including systemic steroids ( $>5 \mathrm{mg} / \mathrm{kg} /$ day), immunotherapy or chemotherapy), chronic kidney disease of grade IIIB or more and hepatic insufficiency. Surgical data included type of prosthetic device, type of surgery (one-step, two-step, arthrodesis ...), infection site and microbiological data (bacterial species, number of positive samples). We classified infections as "early" or "late" when they occurred less than 3 months or more than 12 months after prosthetic device implantation, respectively [18]. We retrieved antibiotics course details including the duration (in days) and dosage of RIF, as well as the occurrence of AEs, their severity using the Common Terminology Criteria for Adverse Events (CTCAE) grades [23] and their consequences on patient management.

Staphylococcus aureus (SA) PJI were defined as the isolation of a SA strain (alone or not) in a surgical periprosthetic sampling. Coagulase negative Staphylococcus (CNS) PJI diagnosis required at least one positive intraoperative sample with compatible clinical characteristics, such as joint pain, fistula, local inflammation or presence of pus during surgery. Polymicrobial infections were defined by the co-identification of two or more bacterial species including Staphylococcus spp.

The primary endpoint was patient recovery, defined as being free of infection during 12 months after the end of the initial antibiotic course.

Secondary endpoints were adverse effects (AEs) and treatment failure (i.e recurrence, relapse, loss to follow-up and death). Recurrence was defined as a new PJI due to the same germ(s) as the initial infection, less than 12 months after the end of the antibiotic course. Relapse was defined as the occurrence of a new PJI due to different germ than initially, in the same interval. When 12 months clinical follow-up data were not available, patients were deemed lost to follow-up. Finally, death occurring

Table 2 Outcome for patients treated with Rifampicin for the full length of treatment $(n=321 / 411$ )

\begin{tabular}{lllll}
\hline & Total & Low-dose & Intermediate-dose & High-dose \\
\hline Recovery, $\mathrm{n}(\%)$ & $237(73.8)$ & $10(55.5)$ & $189(76.2)$ & $38(69)$ \\
Treatment failure, $\mathrm{n}(\%)$ & $52(16.2)$ & $5(27.8)$ & $35(14.1)$ & $12(21.8)$ \\
Lost to follow-up, $\mathrm{n}(\%)$ & $32(10)$ & $3(16.7)$ & $24(9.7)$ & $5(9.1)$ \\
\hline
\end{tabular}


Table 3 Prognostic factors associated with treatment failure (univariate analysis)

\begin{tabular}{|c|c|c|c|}
\hline Variables & Recovery & Failure & $p$ \\
\hline \multicolumn{4}{|c|}{ Number of germs identified } \\
\hline$\leq 1$ & $178(43.3)$ & $126(30.7)$ & 0.655 \\
\hline$>1$ & $64(15.6)$ & $43(10.5)$ & \\
\hline \multicolumn{4}{|l|}{ Sex, n (\%) } \\
\hline Female & $99(24.1)$ & $89(21.6)$ & 0.012 \\
\hline Male & $143(34.8)$ & $80(19.6)$ & \\
\hline \multicolumn{4}{|l|}{ Rifampicin dosage } \\
\hline$<10 \mathrm{mg} / \mathrm{kg} /$ day & $11(2.7)$ & $16(3.9)$ & 0.149 \\
\hline $10-20 \mathrm{mg} / \mathrm{kg} /$ day & $192(46.7)$ & $127(30.9)$ & \\
\hline$>20 \mathrm{mg} / \mathrm{kg} /$ day & $39(9.5)$ & $26(6.3)$ & \\
\hline
\end{tabular}

during 12 months follow-up was considered as treatment failure.

\section{Statistical analysis}

Quantitative variables were expressed as means and standard deviations (SD) when the distribution was normal, and median and interquartile ranges (IQR) otherwise. Normality was measured by the Skewness test. Qualitative variables were expressed as percentages. A proportion comparison test was used to analyze the qualitative variables. Fisher's exact test was used to compare the quantitative variables. A $p$-value below 0.05 was considered significant. A logistic regression model was used to determine risk factors for failure and to account for selection bias. All statistical analyses were performed using STATA 13.1 (StataCorp, College Station, TX).

\section{Ethics}

The study was approved by the CNIL agency (Commission Nationale Informatique et Liberté) in compliance with local and national regulations, under the number PI2019_843_0068.

\section{Results}

From January 2008 until December 2018, 837 patients were treated for PJI due to Staphylococcus spp. (Fig. 1). A total of 411 patients were included (223 males,

Table 4 Prognostic factors associated with treatment failure (multivariate analysis)

\begin{tabular}{lll}
\hline & OR [95\% Cl] & $\mathbf{p}$ \\
\hline Age & $0,94[0.91-0.97]$ & 0.001 \\
Sex & $0.86[0.30-2.44]$ & 0.773 \\
Rifampicin dosage, $\mathrm{mg} / \mathrm{kg} /$ day & $1,02[0.9-1.15]$ & 0.753 \\
Treatment duration, days & $1,05[1.03-1.07]$ & $<0.001$ \\
\hline
\end{tabular}

$54.25 \%$ ) with a median age of 64.5 years (IQR [55-76], extremes 18 to 95 years), and a median weight of $82.5 \mathrm{~kg}$ (IQR [68-95]). (The flow chart is detailed in Fig. 1). However only 321 patients (78\%) received RIF for the full length of treatment, while in 90 patients (22\%) it was discontinued early because of AEs. The characteristics of the patients are detailed in Table 1.

Recovery rate was not statistically different between different groups of RIF dose: 55,6\%, 76,2 and 67.3\% in low-dose, intermediate-dose and high-dose groups respectively $(p=0.083)$ (Table 2$)$. Results were similar while grouping low and intermediate dose-groups: the recovery rate was $74.8 \%$ in the $<20 \mathrm{mg} / \mathrm{kg} /$ day group and $67.3 \%$ in the $>20 \mathrm{mg} / \mathrm{kg} /$ day group. This was true when including patients who discontinued RIF before the end of treatment: $62.6 \%$ of recovery rate in the $<20$ $\mathrm{mg} / \mathrm{kg} /$ day group, and $62.9 \%$ in the $>20 \mathrm{mg} / \mathrm{kg} /$ day group $(p=0.310)$.

In a univariate analysis, being a female was the only variable associated with a lower recovery rate $(p=$ 0.012), no association was found between recovery and RIF dosage or Staphylococcus phenotype (SA or CNS) or the number of germs on intraoperative sampling (Table 3$)$. In a multivariate analysis, older age $(\mathrm{p}=0.01)$ and shorter treatment duration ( $<60$ days, $p<0.01$ ) were significantly associated with treatment failure (Table 4).

Seventy percent of PJI were due to $S A(n=289)$ with $82.4 \%$ of Meticillin-sensitive $S A$ (MSSA), while only $54.9 \%(n=67)$ of CNS were Meticillin-sensitive. The most frequently identified CNS species was Staphylococcus epidermidis (67.8\%). Infections were polymicrobial in $26 \%$ of cases $(n=107)$. Recovery rate was not statistically different according to staphylococcal resistance profile or in polymicrobial infections.

Median RIF dosage was $15.7 \mathrm{mg} / \mathrm{kg} /$ day (IQR [8-18], extremes $5.8-41 \mathrm{mg} / \mathrm{kg} /$ day) and only 27 patients $(6.6 \%)$ received low-dose RIF $(<10 \mathrm{mg} / \mathrm{kg} /$ day $)$. The median duration of the antibiotic course was 39 days (IQR [960]). RIF was mainly combined with fluoroquinolones (67.6\%), clindamycin (15.6\%) or glycopeptides $(8.7 \%)$.

AEs attributable to RIF were reported in 106 patients (26\%), leading to treatment suspension in 65 (61.3\% of AEs), with a median treatment duration of 12.5 days at occurrence (IQR [5-21]). Dosage was discreased in 2 patients, and galenic was changed in 6 patients In 31 cases (29.2\% of AEs), no modification was done despite middle AEs. The most frequent AEs were digestive $(n=51)$, hepatic $(n=12)$ and cutaneous $(n=11)$, usually benign with grades I - II in 75 cases $(70.8 \%$ of AEs). Fifteen patients presented with grade III - IV, mainly digestive $(n=10)$ AEs. AE occurrence rate was $20.9 \%$ in the mediumdose group versus $5.2 \%$ in the high-dose group ( $p=$ 
Table 5 Safety analysis

\begin{tabular}{|c|c|c|c|c|}
\hline & Total & Low-dose & Intermediate-dose & High-dose \\
\hline \multicolumn{5}{|l|}{ AE occurrence, $n(\%)$} \\
\hline Yes & $106(25.8)$ & $5(18.5)$ & $81(25.4)$ & $20(30.8)$ \\
\hline No & $281(68.4)$ & $18(66.7)$ & $220(69)$ & $43(66.2)$ \\
\hline Unknown & $24(5.8)$ & $4(14.8)$ & $18(5.6)$ & $2(3.1)$ \\
\hline \multicolumn{5}{|l|}{ Type of $\mathrm{AE}, \mathrm{n}(\%)$} \\
\hline Digestive & $51(48.1)$ & $2(40)$ & $36(44.4)$ & $12(60)$ \\
\hline Hepatic & $12(11.3)$ & $2(40)$ & $11(13.6)$ & $0(0)$ \\
\hline Cutaneous & $11(10.4)$ & $0(0)$ & $8(9.9)$ & $2(10)$ \\
\hline Renal & $3(2.8)$ & $0(0)$ & $2(2.5)$ & $1(5)$ \\
\hline Hematological & $2(1.9)$ & $0(0)$ & $2(2.5)$ & $0(0)$ \\
\hline General & $1(0,94)$ & $0(0)$ & $1(1,2)$ & $0(0)$ \\
\hline Neurologic & $1(0,94)$ & $0(0)$ & $1(1,2)$ & $0(0)$ \\
\hline$>1 \mathrm{AE}$ types & $23(21,8)$ & $1(20)$ & $17(20,9)$ & $4(20)$ \\
\hline Not specified & $1(0,94)$ & $0(0)$ & $1(1,2)$ & $1(5)$ \\
\hline Unknown & $1(0,94)$ & $0(0)$ & $2(2,5)$ & $0(0)$ \\
\hline \multicolumn{5}{|l|}{ AE severity grade, $n(\%)$} \\
\hline $\mid-\|$ & $75(70.8)$ & $3(60)$ & $53(65.4)$ & $16(80)$ \\
\hline III - IV & $15(14.2)$ & $2(40)$ & $10(12.3)$ & $2(10)$ \\
\hline Unknown & $16(15)$ & $0(0)$ & $18(22.2)$ & $2(10)$ \\
\hline \multicolumn{5}{|c|}{ AE consequences on patient management } \\
\hline Antibiotic change & $62(58.5)$ & $5(100)$ & $50(61.7)$ & $7(35)$ \\
\hline Rifampicin continuation & $32(30.2)$ & $0(0)$ & $20(24.7)$ & $11(55)$ \\
\hline Galenic change & $6(5.7)$ & $0(0)$ & $4(4.9)$ & $2(10)$ \\
\hline Dosage decrease & $2(1.9)$ & $0(0)$ & $2(2.5)$ & $0(0)$ \\
\hline Antibiotic discontinuation & $4(3.8)$ & $0(0)$ & $4(4.9)$ & $0(0)$ \\
\hline Unknown & $0(0)$ & $0(0)$ & $1(1.2)$ & $0(0)$ \\
\hline
\end{tabular}

0.640 ), and $1.3 \%$ in the low-dose group (Table 5). Neither obesity $(\mathrm{BMI}>30)$ nor comorbidities were a risk factor of AEs.

\section{Discussion}

In our study, there was no difference in recovery rate between low-dose and high-dose RIF containing regimens for PJI due to Staphylococcus spp., both in patients who continued treatment for the recommended duration $(p=0.083)$ and in those who discontinued RIF early $(p=0.31)$. These findings are in line with previously published data in favor of using lower doses of RIF, without risking treatment failure $[12,20]$. However, the absence of statistical difference could be attributed to the low power of our study $(1-\beta=0.221, \alpha$ risk $=0.05)$, despite our relatively large sample size.

Treatment failure was significantly associated with duration of RIF treatment ( $<60$ days), but not with the dose. This finding is consistent with DATIPO study results, which found a higher risk of treatment failure with shorter courses of antibiotics (<45 days) [24]. Another randomized multi-center clinical trial also demonstrated the non-inferiority of a combined 8-week fluoroquinolone-RIF regimen, versus 3 or 6 months for hip or knee prostheses respectively, using debridement and implant retention [25].

The rate of AEs attributable to RIF was higher in our study population compared to previously published series, in which the percentage varies from 2 to $15 \%$ [10, $13,26,27]$. One could blame our relatively high RIF dose compared to these studies where doses ranged from 600 $\mathrm{mg}[28-30]$ to $900 \mathrm{mg}$ daily $[26,31]$ regardless of patient weight. However AE occurrence was the highest in the $10-20 \mathrm{mg} / \mathrm{kg} /$ day group and the lowest in the $>20 \mathrm{mg} /$ $\mathrm{kg} /$ day $(5.2 \%)$.Several studies have similarly reported that high dose of RIF (>30/mg/ kg/day) could be used safely over a long period for the treatment of tuberculosis [32, 33]. Conversely, Hagihara et al. suggested that the toxicity associated with prolonged combined antibiotics therapy could be limited by lowering RIF dose [34] 
Valour et al. found a $6.5 \% \mathrm{AE}$ rate for a median RIF dose of $18.8 \mathrm{mg} / \mathrm{kg} /$ day, with a smaller study population $(n=$ 107) [18]. On the other hand, Randuineau et al. more recently suggested a two-fold increase in AEs in patients treated with RIF at $>12$ versus $<12 \mathrm{mg} / \mathrm{kg} /$ day, leading to more frequent treatment discontinuation but without any significant reduction in recovery [20].

The poor tolerance of RIF could thus be solely attributable to inter-individual susceptibilities. Yet, multiple studies failed to show any influence of sex, age, height or weight on pharmacokinetic parameters of RIF [22, 35, 36]. Furthermore, studies by Roblot et al. and Dupouey et al. did not demonstrate any association between RIF serum concentrations and the occurrence of AEs neither digestive nor else [16, 17]. Besides, RIF usage should not be limited to non-comorbid patients, given the safety data of this study and previous ones [37]. While the value of pharmacological monitoring during RIF containing regimen remains unproven pharmacogenetics studies could be of help in the future [17]. Biological and clinical surveillance remain the pillar of PJI followup to prevent a potential harmful RIF discontinuation due to the use of less powerful antibiotics [11, 19, 27, 38-40].

In addition, we did not find lower recovery rates in patients with methicillin-resistant Staphylococci, in line with previous studies $[28,41,42]$, or in patients with polymicrobial infections, in contrast to a study by Senneville et al. [19].

This study has some limitations. Missing data are inherent to the retrospective nature of our work, cutting off 102 patients from our initial sample. The low number of patients receiving low-dose RIF has probably contributed to our low study power.

\section{Conclusion}

In conclusion, our data show the feasibility of using lower doses of RIF than these currently advised by national guidelines, which is consistent with the results of several observational studies $[12,20,28,29,31]$. A national French randomized controlled trial (PHRC EVRIOS - NTC 02599493), programmed for 2021, aims to include 460 patients, with the goal of determining optimal RIF dosage $(<10$ or $>20 \mathrm{mg} / \mathrm{kg} /$ day $)$ in PJI due to Staphylococcus spp., and will probably definitely answer this question.

\footnotetext{
Abbreviations

AE: Adverse effects; CTCAE: Common Terminology Criteria for Adverse Events; EMR: Electronic Medical Records; IQR: Interquartile ranges; PJI: Joint prosthetic device infections; RIF: Rifampicin; SA: Staphylococcus aureus; SD: Standard deviations
}

\section{Acknowledgements}

Acknowledgements go to M.LECURU, B.HOMBERT, G.AMOUGAY and K.EL HUSSEINI for their technical assistance.

\section{Authors' contributions}

MT was a major contributor in writing the manuscript. $\mathrm{AB}, \mathrm{CM}$ and $\mathrm{CJ}$ analyzed patient data. YES and JLS ensured patient follow-up. JPL interpreted the patient data. BB was the othopedic surgeon in charge of the septic unit. All authors read and approved the final manuscript.

\section{Funding}

Not applicable.

\section{Availability of data and materials}

The datasets used and/or analysed during the current study are available from the corresponding author on reasonable request.

\section{Ethics approval and consent to participate}

This study was approved by the CNIL agency (Commission Nationale Informatique et Liberté) in compliance with local and national regulations, under the number PI2019_843_0068. Data used in this study was anonymised before its use.

\section{Consent for publication}

Not applicable.

\section{Competing interests}

The authors declare that they have no competing interests.

\section{Author details}

${ }^{1}$ Infectious diseases department, CHU Amiens Nord, 1 place Victor Pauchet, 80000 Amiens, France. ${ }^{2}$ Centre hospitalier Compiègne-Noyon - service MIPI, 8 avenue Henri Adnot, 60200 Compiègne, France. ${ }^{3}$ UR 4294 AGIR, Université Picardie Jules Verne, 1-3 rue des Louvels, 80000 Amiens, France. ${ }^{4}$ Orthopedic department, CHU Amiens Sud, 1 rue du Professeur Christian Cabrol, 80054 Amiens, France. ${ }^{5}$ Pharmacy department, CHU Amiens Sud, 1 rue du Professeur Christian Cabrol, 80054 Amiens, France.

Received: 1 September 2020 Accepted: 22 January 2021

Published online: 12 February 2021

\section{References}

1. Grammatico-Guillon L, Baron S, Gettner S, Lecuyer A-I, Gaborit C, Rosset P, Rusch E, Bernard L. Bone and joint infections in hospitalized patients in France, 2008: clinical and economic outcomes. J Hosp Infect. 2012;82(1):408.

2. Zimmerli W, Trampuz A, Ochsner PE. Prosthetic-joint infections. N Engl J Med. 2004:351(16):1645-54.

3. Zmistowski B, Karam JA, Durinka JB, Casper DS, Parvizi J. Periprosthetic joint infection increases the risk of one-year mortality. J Bone Joint Surg Am. 2013;95(24):2177-84

4. Laurent E, Gras G, Druon J, Rosset P, Bernard L, Grammatico-Guillon L. Évolution des infections ostéo-articulaires (IOA) en France après mise en place des centres de références des IOA complexes (CRIOAC) : PMSI 2008 versus 2013. Rev DÉpidémiologie Santé Publique. 2016;64:S23-4.

5. Kapadia BH, Banerjee S, Cherian JJ, Bozic KJ, Mont MA. The economic impact of Periprosthetic infections after Total hip Arthroplasty at a specialized tertiary-care center. J Arthroplast. 2016;31(7):1422-6.

6. Parvizi J, Pawasarat IM, Azzam KA, Joshi A, Hansen EN, Bozic KJ. Periprosthetic joint infection: the economic impact of methicillin-resistant infections. J Arthroplastyt. 2010;25(6 Suppl):103-7.

7. Saginur R, Stdenis M, Ferris W, Aaron SD, Chan F, Lee C, Ramotar K. Multiple combination bactericidal testing of staphylococcal biofilms from implantassociated infections. Antimicrob Agents Chemother janv. 2006;50(1):55-61.

8. LaPlante $\mathrm{KL}$, Woodmansee $\mathrm{S}$. Activities of daptomycin and vancomycin alone and in combination with rifampin and gentamicin against biofilmforming methicillin-resistant Staphylococcus aureus isolates in an experimental model of endocarditis. Antimicrob Agents Chemother sept. 2009;53(9):3880-6.

9. Société de Pathologie Infectieuse de Langue Française (SPILF), Collège des Universitaires de Maladies Infectieuses et Tropicales (CMIT), Groupe de Pathologie Infectieuse Pédiatrique (GPIP), Société Française d'Anesthésie et de Réanimation (SFAR), Société Française de Chirurgie Orthopédique et Traumatologique (SOFCOT), Société Française d'Hygiène Hospitalière (SFHH), Société Française de Médecine Nucléaire (SFMN), Société Française de 
Médecine Physique et de Réadaptation (SOFMER), Société Française de Microbiologie (SFM), Société Française de Radiologie (SFR-Rad), Société Française de Rhumatologie (SFR-Rhu). [Recommendations for clinical practice. Osteo-articular infection therapy according to materials used (prosthesis, implants, osteosynthesis)]. Med Mal Infect. oct 2009;39(10):74574 .

10. El Helou OC, Berbari EF, Lahr BD, Eckel-Passow JE, Razonable RR, Sia IG, Virk A, Walker RC, Steckelberg JM, Wilson WR, Hanssen AD, Osmon DR. Efficacy and safety of rifampin containing regimen for staphylococcal prosthetic joint infections treated with debridement and retention. Eur J Clin Microbiol Infect Dis Off Publ Eur Soc Clin Microbiol. 2010;29(8):961-7.

11. Optimizing combination rifampin therapy for staphylococcal osteoarticular infections - ScienceDirect [Internet]. [cité 19 janv 2020]. Disponible sur: https://www.sciencedirect.com/science/article/pii/S1297319X1200213 8?via\%3Dihub

12. Influence of daily dosage and frequency of administration of rifampicinlevofloxacin therapy on tolerance and effectiveness in 154 patients treated for prosthetic joint infections | SpringerLink [Internet]. [cité 19 janv 2020]. Disponible sur: https://ink.springer.com/article/10.1007\%2Fs10096-015-2404-z

13. Drancourt M, Stein A, Argenson JN, Zannier A, Curvale G, Raoult D. Oral rifampin plus ofloxacin for treatment of Staphylococcus-infected orthopedic implants. Antimicrob Agents Chemother. 1993;37(6):1214-8.

14. Osmon DR, Berbari EF, Berendt AR, Lew D, Zimmerli W, Steckelberg JM, Rao N, Hanssen A, Wilson WR. Infectious Diseases Society of America. Executive summary: diagnosis and management of prosthetic joint infection: clinical practice guidelines by the Infectious Diseases Society of America. Clin Infect Dis Off Publ Infect Dis Soc Am. 2013;56(1):1-10.

15. Frippiat F, Meunier F, Derue G. Place of newer quinolones and rifampicin in the treatment of gram-positive bone and joint infections. J Antimicrob Chemother. 2004;54(6):1158 author reply 1159.

16. COL08-04 : Suivi thérapeutique pharmacologique (STP) de la rifampicine (RIF) dans les infections ostéo-articulaires (IOA) - EM|consulte [Internet]. [cité 19 janv 2020]. Disponible sur: https://www.em-consulte.com/en/article/904912

17. Lack of association between rifampicin plasma concentration and treatment-related side effects in osteoarticular infections - Roblot - 2007 Fundamental \&amp; Clinical Pharmacology - Wiley Online Library [Internet]. [cité 19 janv 2020]. Disponible sur: https://onlinelibrary.wiley.com/doi/abs/1 0.1111/j.1472-8206.2007.00490.x

18. Valour F, Karsenty J, Bouaziz A, Ader F, Tod M, Lustig S, Laurent F, Ecochard $R$, Chidiac C, Ferry T. Antimicrobial-related severe adverse events during treatment of bone and joint infection due to methicillin-susceptible Staphylococcus aureus. Antimicrob Agents Chemother. 2014;58(2):746-55.

19. Senneville $E$, Joulie $D$, Legout $L$, Valette $M$, Dezèque $H$, Beltrand E, Roselé $B$, d'Escrivan T, Loïez C, Caillaux M, Yazdanpanah Y, Maynou C, Migaud H. Outcome and predictors of treatment failure in total hip/knee prosthetic joint infections due to Staphylococcus aureus. Clin Infect Dis Off Publ Infect Dis Soc Am. 2011;53(4):334-40.

20. Randuineau P, Bouchand F, Matt M, Villart M, Davido B, Nich C, Dinh A. Efficacité et tolérance de la rifampicine dans le traitement des infections ostéo-articulaires. Médecine Mal Infect. 2019;49(4, Supplement):S85-6.

21. Alsultan A, Peloquin CA. Therapeutic drug monitoring in the treatment of tuberculosis: an update. Drugs. 2014;74(8):839-54.

22. Jing $Y$, Zhu LQ, Yang JW, Huang SP, Wang Q, Zhang J. Population pharmacokinetics of rifampicin in Chinese patients with pulmonary tuberculosis. J Clin Pharmacol. 2016;56(5):622-7.

23. Common Terminology Criteria for Adverse Events (CTCAE). 2017;147

24. Bernard L. Durée d'Antibiothérapie (6 versus 12 s) pour le Traitement des Infections sur Prothèse Ostéoarticulaires, vol. 32; 2019.

25. J L-T, G E, J C, Jp H, A S, E S, C P, N B, L F, J P, Md DT, A J-S, Ja I, M S-S, A R, M F-S, M R, Jm B-E, J A. Short- Versus Long-Duration Levofloxacin Plus Rifampicin for Acute Staphylococcal Prosthetic Joint Infection Managed With Implant Retention: A Randomised Clinical Trial [Internet]. International journal of antimicrobial agents. 2016 [cité 6 juin 2020]. Disponible sur: https://pubmed.ncbi.nlm.nih.gov/27524103/?from_term=prosthetic+joint+ infection+rifampicin+staphylocoque\&from_exact_term=prosthetic\%5Btitl $\% 5$ D+AND+joint\%5Btit|\%5D+AND+infection\%5Btit|\%5D+AND+rifampicin\%5 Btitl\%5D\&from_pos=1

26. Zimmerli W, Widmer AF, Blatter M, Frei R, Ochsner PE. Role of rifampin for treatment of orthopedic implant-related staphylococcal infections: a randomized controlled trial. Foreign-Body Infection (FBI) Study Group. JAMA. 1998;279(19):1537-41.
27. Widmer AF, Gaechter A, Ochsner PE, Zimmerli W. Antimicrobial treatment of orthopedic implant-related infections with rifampin combinations. Clin Infect Dis Off Publ Infect Dis Soc Am. 1992;14(6):1251-3.

28. Barberán J, Aguilar L, Carroquino G, Giménez M-J, Sánchez B, Martínez D, Prieto J. Conservative treatment of staphylococcal prosthetic joint infections in elderly patients. Am J Med. 2006;119(11):993.e7-10.

29. Soriano A, Garcia S, Bori G, et al. Treatment of acute post-surgical infection of joint arthroplasty. Clin Microbiol Infect. 2006;12:930-3.

30. Aboltins CA, Page MA, Buising KL, et al. Treatment of staphylococcal prosthetic joint infections with debridement, prosthesis retention and oral rifampicin and fusidic acid. Clin Microbiol Infect. 2007;13:586-91.

31. Drancourt M, Stein A, Argenson JN, Roiron R, Groulier P, Raoult D. Oral treatment of Staphylococcus spp infected orthopaedic implants with fusidic acid or ofloxacin in combination with rifampicin. J Antimicrob Chemother. 1997;39(2):235-40.

32. Seijger C, Hoefsloot W, Bergsma-de Guchteneire I, te Brake L, van Ingen J, Kuipers S, van Crevel R, Aarnoutse R, Boeree M, Magis-Escurra C. High-dose rifampicin in tuberculosis: Experiences from a Dutch tuberculosis centre. PLoS ONE [Internet]. 14 mars 2019 [cité 6 juin 2020];14(3). Disponible sur: https://www.ncbi.nlm.nih.gov/pmc/articles/PMC6417786/

33. $M j B, A h D, R D, K N$, J du B, A V, Pp P, Sh G, Td M, M H, N H, S R, D van S, J van I, C M-E, D B, G P van B, Re A. A Dose-Ranging Trial to Optimize the Dose of Rifampin in the Treatment of Tuberculosis [Internet]. American journal of respiratory and critical care medicine. 2015 [cité 6 juin 2020]. Disponible sur: https://pubmed.ncbi.nlm.nih.gov/25654354/

34. Hagihara M, Crandon JL, Nicolau DP. The efficacy and safety of antibiotic combination therapy for infections caused by gram-positive and gramnegative organisms. Expert Opin Drug Saf. 2012;11(2):221-33.

35. Population pharmacokinetics of rifampicin in adult patients with osteoarticular infections: interaction with fusidic acid [Internet]. [cité 19 janv 2020]. Disponible sur: https://www.ncbi.nlm.nih.gov/pmc/articles/PMC5401979/

36. Seng K-Y, Hee K-H, Soon G-H, Chew N, Khoo SH, Lee LS-U. Population pharmacokinetics of rifampicin and 25-deacetyl-rifampicin in healthy Asian adults. J Antimicrob Chemother. déc. 2015;70(12):3298-306.

37. Grosset J, Leventis S. Adverse effects of rifampin. Rev Infect Dis. 1983; 5(Suppl 3):S440-50.

38. Laffer RR, Graber P, Ochsner PE, Zimmerli W. Outcome of prosthetic kneeassociated infection: evaluation of 40 consecutive episodes at a single Centre. Clin Microbiol Infect Off Publ Eur Soc Clin Microbiol Infect Dis mai. 2006;12(5):433-9.

39. Management of infections of osteoarticular prosthesis. - PubMed - NCBI [Internet]. [cité 19 janv 2020]. Disponible sur: https://www.ncbi.nlm.nih.gov/ pubmed/16669932

40. Berdal J-E, Skråmm I, Mowinckel P, Gulbrandsen P, Bjørnholt JV. Use of rifampicin and ciprofloxacin combination therapy after surgical debridement in the treatment of early manifestation prosthetic joint infections. Clin Microbiol Infect Off Publ Eur Soc Clin Microbiol Infect Dis oct. 2005;11(10):843-5.

41. Choong PFM, Dowsey MM, Carr D, Daffy J, Stanley P. Risk factors associated with acute hip prosthetic joint infections and outcome of treatment with a rifampinbased regimen. Acta Orthop. 2007;78(6):755-65.

42. Vilchez F, Martínez-Pastor JC, García-Ramiro S, Bori G, Maculé F, Sierra J, Font L, Mensa J, Soriano A. Outcome and predictors of treatment failure in early post-surgical prosthetic joint infections due to Staphylococcus aureus treated with debridement. Clin Microbiol Infect Off Publ Eur Soc Clin Microbiol Infect Dis. 2011;17(3):439-44.

\section{Publisher's Note}

Springer Nature remains neutral with regard to jurisdictional claims in published maps and institutional affiliations. 